FEATURING:

281

United States Supreme Court: Medellin v. Texas

Introductory Note by Mark E. Wojcik

322

Extraordinary Chambers in the Courts of Cambodia Pre-Trial Chamber Decision on Appeal against Provisional Detention Order of Kaing Guek Eav

Introductory Note by Scott Lyons

336

European Court of Human Rights: Lindon, Otchakovsky-Laurens and July v. France

Introductory Note by John Cerone

372

World Trade Organization: Measures Affecting the Supply of Gambling and Betting Services (Award) Introductory Note by Sungjoon Cho

445

International Centre for the Settlement of Investment Disputes (ICSID): Azurix Corp. v. The Argentine Republic Decision on Argentine Republic's Request for a Continued Stay of Enforcement of the Award Introductory Note by Alejandro Escobar 


\section{Your Resource For The Latest And Best In International Law}

\section{The AMERICAN SOCIETy OF INTERNATIONAL LAW}

American Journal of International Law

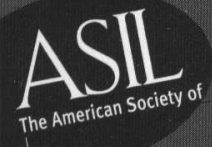

Proceedings of the 99th Meeting

March 30-April 2, 200 Washington, DC
SINCE I906, THE ASIL HAS KEPT INDIVIDUALS

AND INSTITUTIONS AROUND THE WORLD UP-TO-DATE WITH THE BEST INFORMATION ON

INTERNATIONAL LAW.

Through ITS

MEMBERSHIP PROGRAM, FLAGSHIP PUBLICATIONS, ELECTRONIC INFORMATION BULLETINS, AND RENOWNED MEETINGS AND NETWORKING OPPORTUNITIES, THE ASIL LEADS THE FIELD.

TO LEARN MORE, VISIT www.asil.org. 


\section{The Law and Economics of Contingent Protection in the WTO}

Petros C. Mavroidis, Columbia Law School, US and University of Neuchatel, Switzerland,

Patrick A. Messerlin, Groupe d’Economie Mondiale at Sciences Po, France and Jasper M. Wauters, White \& Case International Trade, Switzerland

Although the legal landscape is littered with literature about the WTO, antidumping, safeguards, subsidies and countervailing measures, the missing piece has been a comprehensive text tying together the law and economics of these topics. Mavroidis, Messerlin and Wauters fill this gap. The authors form an unparalleled triumvirate who successfully draw on their complementary legal-economic experiences from policymaking, practitioner expertise and academic scholarship to comprehensively examine contingent protection. In a single book, they manage to explain the economics to the lawyers, the law to the economists, and the increasing importance of contingent protection policies to everyone.'

- Chad P. Bown, Brandeis University, US

'The new book by Petros Mavroidis, Patrick Messerlin and Jasper Wauters, The Law and Economics of Contingent Protection in the WTO, fills a gap in the international trade literature by providing a comprehensive, interdisciplinary (law and economics) treatment of three of the most arcane and least wellunderstood trade protection regimes permitted under the GATTMTO, i.e., antidumping, countervailing duties, and safeguards. The authors expertly weave together both a comprehensive and rigorous analysis of the complex legal rules and case law with an economic critique of the law governing each of these three regimes. The book is a tour de force and will become the standard reference work for scholars, policy makers, and practitioners specializing in these areas.

- Michael Trebilcock, University of Toronto, Canada

June 2008640 pp Hardback $9781847202765 \$ 220.00$

Elgar International Economic Law series

\section{MORE INFORMATION}

Edward Elgar Publishing Inc. • William Pratt House - 9 Dewey Court Northampton, MA 01062-3815 USA

Tel: (413) 584-5551 • Fax: (413) 584-9933 • elgarinfo@e-elgar.com

\section{ORDERS}

Edward Elgar Publishing Inc. • PO Box 574

Williston, VT 05495-0575 USA

Tel: (800) 390-3149 • Fax (802) 864-7626 • eep.orders@aidcvt.com

www.e-elgar-law.com

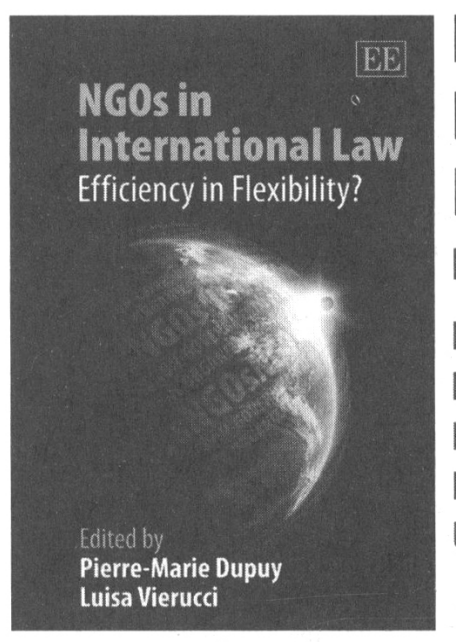

NGOs in International Law

Efficiency in Flexibility?

Edited by

Pierre-Marie Dupuy,

European University

Institute and Luisa Vierucci,

University of Florence, Italy

'The increasing importance of NGOs has forced international institutions to pay attention to issues of participation and transparency. This excellent book provides comprehensive and insightful analyses of how international bodies accommodate NGOs and their concerns. It forthrightly addresses the uncertain legal status of NGOs in international law.

\section{- Edith Brown Weiss, Georgetown University Law Center, US}

'No one can deny the significance that NGOs have at the international level, or the dynamism some of them have shown in promoting change, whether in the context of the International Criminal Court or the environment, etc. This is a lively and well-informed account of the wide range of NGOS at the international level, their continuing search for status and (what is more important) access, and also of the abuses sometimes involved, e.g. with "servile NGOs" in the human rights field. This collection provides an important source of information about an important source of influence on our lives.'

- James Crawford, Cambridge University, UK

May 2008288 pp Hardback $9781847205605 \$ 140.00$
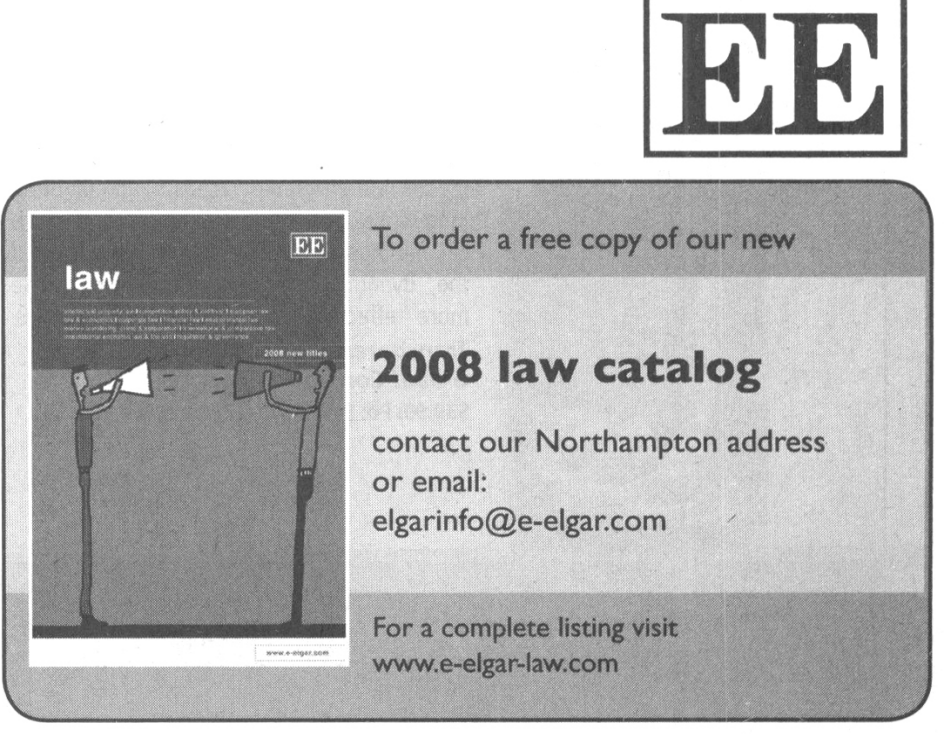


\section{The Best and the Brightest New Scholarship in Law}

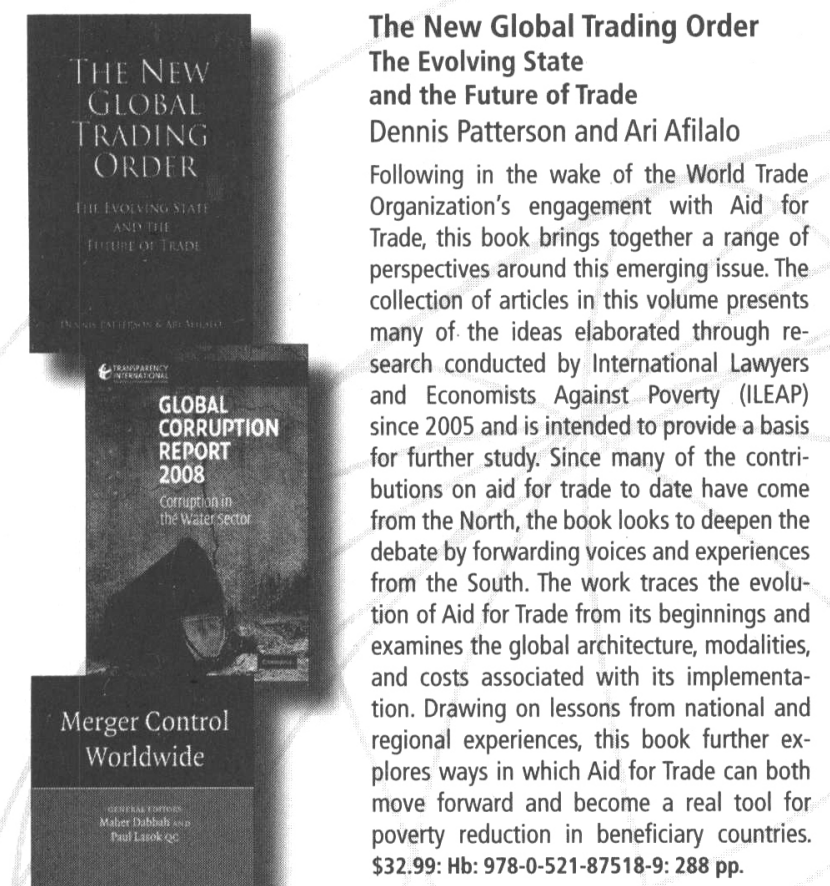

Global Corruption Report 2008

Corruption in the Water Sector

Compiled by

Transparency International

Over one billion people live with inadequate access to safe drinking water with dramatic consequences for lives, livelihoods and development. Transparency international's Global Corruption Report 2008 demonstrates in its thematic section that corruption is a cause and catalyst for this water crisis which is likely to be further exacerbated by climate change. Corruption affects all aspects of the water sector from water resources management to drinking water services, irrigation and hydropower. Scholars and professionals document the impact of corruption in the sector with case studies from all around the world and offer practical suggestions for reform. The second part of the Report provides a snapshot of corruption-related developments in 35 countries from all world regions. The third part presents summaries of corruption-related research, highlighting innovative methodologies and new empirical findings that help to better understand the dynamics of corruption and devise more effective anti-corruption strategies. Transparency International

Global Corruption Reports

\$39.99: Pb: 978-0-521-72795-2: 464 pp.

\author{
Merger Control Worldwide \\ Second Supplement \\ to the First Edition
}

Maher Dabbah and Paul Lasok QC

Merger Control Worldwide is a comprehensive, multi-contributor collection which sets out the details of every jurisdiction where a mechanism for merger control is in place. A concise, practical account is given of the relevant law in each jurisdiction, presented with the aid of flowcharts and diagrams. Merger Control Worldwide aims to provide the legal community, in particular law firms and policymakers, with a clear point of reference that will prove invaluable when making decisions and delivering sound and accurate advice in merger cases. This, the second supplement to Merger Control Worldwide, provides an update on developments that have occurred recently in the field. It includes a comprehensive appraisal of a new jurisdiction, Singapore. Merger Control Worldwide

\$175.00: Pb: 978-0-521-72413-5: 208 pp.

\section{The WTO Case Law of 2004-5}

Henrik Horn and Petros C. Mavroidis

This book brings together the 2004-2005 output of the American Law Institute (ALI) project on World Trade Organization Law. Each chapter focuses on a different dispute from the adjudicating bodies of the WTO. Each case is jointly evaluated by well known experts in trade law and international economics. ALI reporters critically review the jurisprudence of WTO-adjudicating bodies and evaluate whether the ruling 'makes sense' from an economic as well as a legal point of view, and, if not, whether the problem lies in the interpretation of the law or the law itself. The studies do not always cover all issues discussed in a case, but they seek to discuss both the procedural and the substantive issues that form, in the reporters' view, the 'core' of the dispute. This $\mathrm{Pb}$ will be an invaluable resource for students, lecturers and practitioners of international trade law. World Trade Organization \$55.00*: Pb: 978-0-521-73076-1

\section{SECOND EDITION}

The World Trade Organization Knowledge Agreements

\section{Christopher Arup}

This second edition analyzes the provisions of the agreements and examines closely the thirteen years of implementation and revision. Gathering together the interpretations placed on the agreements by the WTO dispute settlement bodies, it reports on the initiatives taken by the members both to liberalize trade in knowledge and to shape international business regulation. Drawing on this, Christopher Arup assesses the future of the WTO as a global law-making institution. Three expanded case studies (legal services, genetic codes/essential medicines, and on-line media) illustrate the impact of the agreements and highlight the challenges faced by the WTO in reconciling free trade with social regulation. Cambridge Studies in Law and Society \$110.00: Hb: 978-0-521-88123-4: $560 \mathrm{pp}$.

Agreeing and Implementing the Doha Round of the WTO Harald Hohmann

The Doha Round is the first major trade negotiation round under the WTO since the failure of the Seattle Ministerial in 1999. The Doha discussions and results will have a large impact on the future of international trade law. Leading scholars and practitioners from three continents comment on four such areas in this book. Firstly, poverty eradication, capacity building, and special and differential treatment are required to change for WTO law to be accepted globally; this may lead to a reinterpretation of WTO law. Secondly, the major trade policy concerns, the global concept of competition, and the impacts of trade facilitation and of sustainability of trade liberalization are examined. The third topic is the improvement of the dispute settlement through, for example, a relaxation of tensions between the judicial and diplomatic models. Finally, possible solutions for the balance between free trade, environmental protection and human rights are explored. \$135.00: Hb: 978-0-521-86990-4: $560 \mathrm{pp}$.

\section{NEW IN PAPERBACK}

The Banning of Anti-Personnel Landmines

The Legal Contribution of the International Committee of the Red Cross 1955-1999 Louis Maresca and Stuart Maslen

The International Committee of the Red Cross has played a key role in the effort to ban antipersonnel landmines. This book provides an overview of the work of the ICRC concerning landmines from 1955 through 1999. It contains International Committee of the Red Cross position papers, working papers, and speeches made by its representatives to the international meetings convened to address the mines issue, including the 1995-96 Review Conference of the 1980 Convention on Certain Conventional Weapons and the diplomatic meeting that adopted the Ottawa treaty banning anti-personnel mines. \$75.00: Pb: 978-0-521-06451-4: 698 pp. 


\section{The Best and the Brightest New Scholarship in Law}

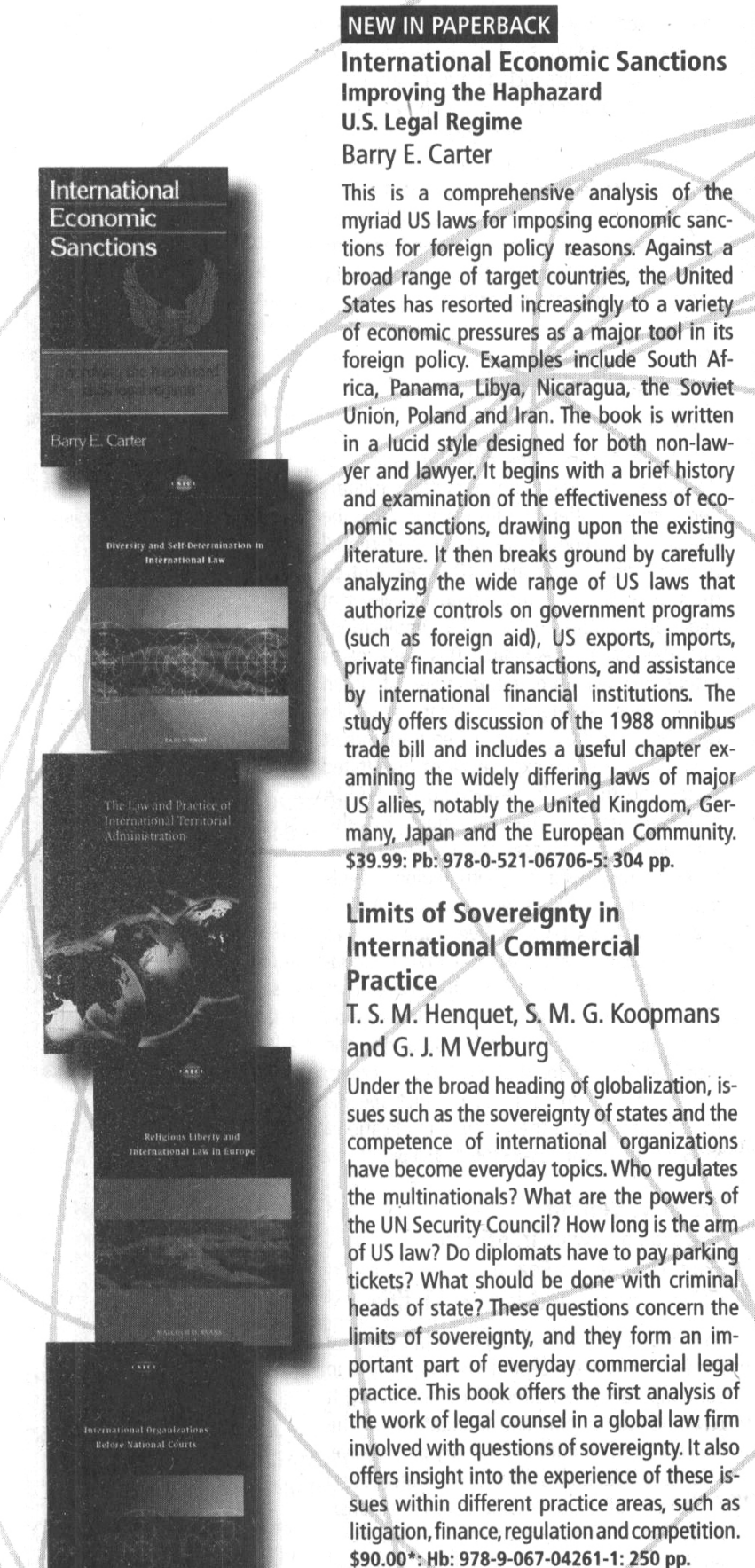

\section{CAMBRIDGE STUDIES IN INTERNATIONAL AND COMPARATIVE LAW}

\section{NEW IN PAPERBACK}

Diversity and Self-Determination in International Law

\section{Karen Knop}

The emergence of new states and independence movements after the Cold War has intensified the long-standing disagreement among international lawyers over the right of self-determination, especially the right of secession. Knop shifts the discussion from the articulation of the right to its interpretation. She argues that the practice of interpretation involves and illuminates a problem of diversity raised by the exclusion of many of the groups that self-determination most affects. Distinguishing different types of exclusion and the relationships between them reveals the deep structures, biases and stakes in the decisions and scholarship on self-determination. Knop's analysis also reveals that the leading cases have grappled with these embedded inequalities. Challenges by colonies, ethnic nations, indigenous peoples, women and others to the gender and cultural biases of international law emerge as integral to the interpretation of self-determination historically, as do attempts by judges and other institutional interpreters to meet these challenges. \$55.00: Pb: 978-0-521-06740-9: 456 pp.

\section{The Law and Practice of} International Territorial

\section{Administration}

Versailles to Iraq and Beyond

Carsten Stahn

This book analyzes the genesis and law and practice of international territorial administration, covering all experiments from the Treaty of Versailles to contemporary engagements such as the conflict in Iraq. The book discusses the background, legal framework and practice of international territorial administration, including its relationship to related paradigms (internationalization, mandate administration, Trusteeship administration and occupation). This is complemented by a discussion of four common legal issues which arise in the context of this activity: the status of the territory under administration, the status and accountability of administering authorities, the exercise of regulatory powers by international administrations, and the relationship between international and domestic actors. Alongside surveys of the existing approaches and conceptual choices, the book also includes relevant case-law and practice and lessons learned for future engagements. \$190.00: Hb: 978-0-521-87800-5: 872 pp.

\section{NEW IN PAPERBACK}

\section{Religious Liberty and}

International Law in Europe

Malcolm D. Evans

In this fascinating book, Malcolm Evans describes in detail the ways in which the freedom of religious belief has been incorporated into the legislation of the countries of Europe. He goes on to examine the mechanisms by which this freedom is guaranteed, and a number of problematic cases that have recently been discussed in the Council of Europe. In a concluding section he outlines a number of developments that will influence the direction that the search for the protection of religious liberty under international law may take. \$48.00: Pb: 978-0-521-04761-6: 427 pp.

\section{NEW IN PAPERBACK}

International Organizations

before National Courts

August Reinisch

This book presents a radical, empirical investigation of how national courts "react" to disputes involving international organizations, analyzing in particular whether such organizations should be immune to national jurisdictions. Under the headings "domestic legal personality" and "immunity" of international organizations, some of the issues covered have already been treated in international legal scholarship, mostly in the form of short articles or case notes. This study, however, provides a thorough comparative analysis and the largest compilation of relevant decisions on the subject, making it indispensable for practitioners as well as academics in the field. \$58.00: Pb: 978-0-521-06364-7: $519 \mathrm{pp}$. 


\section{The Best and the Brightest New Scholarship in Law}

\section{WORLD TRADE FORUM}

GATS and the Regulation of International Trade in Services Marion Panizzon, Nicole Pohl and Pierre Sauvé

This collection of essays takes stock of the key challenges that have arisen since the entry into force of the General Agreement on Trade in Services in the mid-1990s and situates them in the context of the WTO's Doha Development Agenda and the proliferation of preferential agreements addressing services today. The multidisciplinary approach provides an opportunity for many of the world's leading experts and a number of new analytical voices to exchange ideas on the future of services trade and regulation. Cosmopolitan approaches to the treatment of labor mobility, the shape of services trade disciplines in the digital age and pro-competitive regulation in air transport are explored with a view to helping readers gain a better understanding of the forces shaping the changes. An essential read for all those concerned with the evolution of the rules-based trading system and its impact on the service economy. \$150.00: Hb: 978-0-521-89688-7: $688 \mathrm{pp}$.

\section{Genetic Engineering and} the World Trade System Daniel Wüger and Thomas Cottier This book seeks to identify the challenges to international trade regulation that arise from biotechnology. The contributions examine whether existing international obligations of WTO Members are appropriate to deal with the issues arising for the use of biotechnology and whether there is a need for new international legal instruments, including a potential WTO Agreement on Biotechnology. They combine various perspectives on and topics relating to genetic engineering and trade, including human rights and gender; intellectual property rights; traditional knowledge and access and benefit sharing; food security, trade and agricultural production and food safety; and medical research, cloning and international trade. \$120.00: Hb: 978-0-521-88360-3: 366 pp.

\section{A Handbook on}

\section{Accession to the WTO}

A WTO Secretariat Publication

World Trade Organization

Foreword by Arif Hussain

The Handbook provides the first detailed explanation and analysis of the process whereby governments become Members of the WTO. The WTO Agreement, which came into force on 1 January, 1995, provides few details on how this process is to take place. Consequently, the steps in the detailed negotiations leading up to access have evolved through the actual negotiations for governments which have become Members of the WTO since 1995. This Handbook is unique in providing an account of how the process evolved and in offering details on the process as it is now applied. Moreover, the input of the WTO Secretariat into the preparation of the guide provides information not available until now to anyone outside the Secretariat. The Secretariat has supported production of this Handbook in the hope it will serve as a useful source of reference for officials from acceding governments, WTO Members, academia, and the general public \$120.00: Hb: 978-0-521-42594-0: 256 pp. \$48.00: Pb: 978-0-521-72868-3

\section{The Genesis of the GATT}

Douglas A. Irwin, Petros C. Mavroidis and Alan 0. Sykes

The intent of this work is to examine how the GATT emerged from the chaos of World War II to create a system of multilateral cooperation which enabled international trade to flourish for over half a century. The authors, in putting the GATT into historical context, study the diplomatic history that gave rise to the GATT, look at the original goals and intentions of its founders, and explain why the GATT took the shape it did. Annexes with key official documents, many of them previously unpublished, give readers important primary sources they can use to trace the evolution of government proposals and negotiating strategies. While other works on the GATT have studied the GATT as an international legal text or from an international organization point of view, this work provides the first in-depth look at how the GATT came to be.

The American Law Institute

Reporters Studies on WTO Law

\$85.00: Hb: 978-0-521-51561-0: 350 pp.

\section{NEW IN PAPERBACK}

The Political Economy of

International Trade Law

Essays in Honor of Robert E. Hudec

Daniel L. M. Kennedy

and James D. Southwick

In this volume, international experts from law, economics, and political science provide in-depth analysis of international trade issues. Attorneys, economists, and politica scientists adopt an approach which consid ers WTO legal institutions as functioning in unexpected ways due to the political and economic conditions of their international environment. Topics include the constitutional dimensions of international trade law, adding and restructuring existing subjects, the legal relations between developed and developing countries, and the operation of the WTO dispute settle procedure. This will be an essential volume for professionals and academics involved with international trade policy. \$80.00: Pb: 978-0-521-06591-7: 710 pp.

\section{Rules of Origin in}

International Trade

Stefano Inama

This book discusses the different aspects of the rules of origin with a multidisciplinary perspective. It offers the first overview on the status of the negotiations of non-preferential rules of origin under the WTO agreement on rules of origin after more than ten years of negotiations and the possible implications for other WTO agreements. This book deals extensively with preferential rules of origin - both under unilateral trade instruments like GSP, EBA, and AGOA and in free trade areas. Inama analyzes the experience of the United States and the EU in developing the NAFTA and Pan-European rules of origin. He also compares and discusses the parallel experiences of the major southern regional trade agreements - such as Mercosur and ASEAN - and the ASEAN-China free trade area, as well as Comesa and SADC in their negotiations of the European partnership agreements (EPAs) with the EU. It discusses the evolution of the different sets of rules of origin, the technical options for drafting rules of origin, a methodology for drafting product specific rules of origin, and the possible implications. \$135.00: Hb: 978-0-521-85190-9: 350 pp.

\section{Jus Post Bellum}

Towards a Law of Transition

From Conflict to Peace

Carsten Stahn and Jann K. Kleffner

This book sheds a fresh light on the use and relevance of the concept of jus post bellum in contemporary international law and policy. It examines the origins and foundations of the concept from an inter-disciplinary perspective. Moreover, it identifies some of the features and challenges of a framework governing transitions from conflict to peace, such as the treatment of sovereignty, accountability and local ownership, the relationship of jus post bellum to jus ad bellum and jus in bello and the role of human rights law and transitional justice. \$90.00: Hb: 978-9-067-04272-7: $250 \mathrm{pp}$.

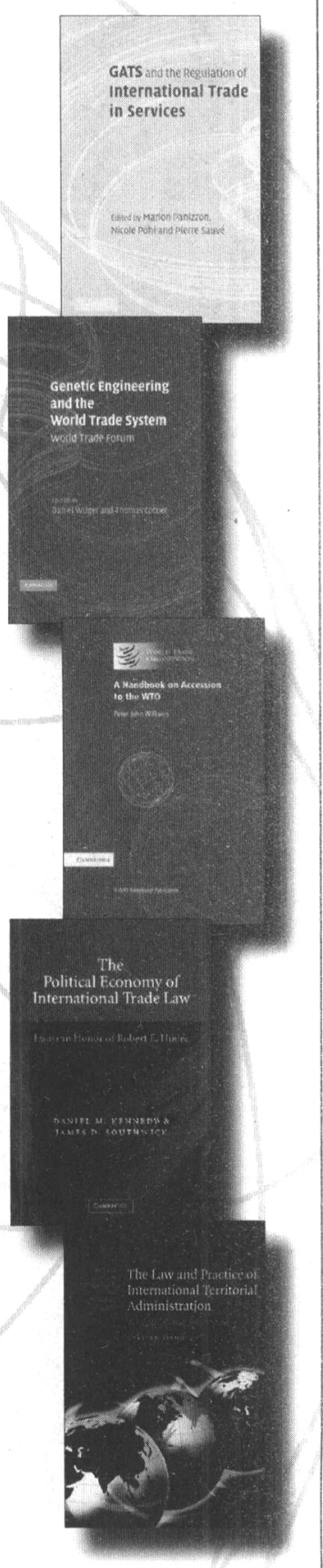




\section{The Best and the Brightest New Scholarship in Law}

\section{The Legal Status of Territories Subject to Administration by International Organizations Bernhard Knoll}

The international community's practice of administering territories in post-conflict environments has raised important legal questions Using Kosovo as a case study, Bernhard Knol analyzes the identity of the administrating UN organ, the ways in which the territories under consideration have acquired partial subjectivity in international law and the nature of legal obligations in the fiduciary exercise of transitional administration developed within the League of Nations' Mandate and the UN Trusteeship systems. Knoll discusses Kosovo's internal political and constitutional order and notes the absence of some of the character istics normally found in liberal democracies, before proposing that the UN consolidates accountability guidelines related to the protection of human rights and the development of democratic standards should it engage in the transitional administration of territory. \$150.00: Hb: 978-0-521-88583-6: 552 pp.

\section{The Right to Self-Determination} and Post-Colonial Governance The Case of the Netherlands Antilles and Aruba

\section{Steven Hillebrink}

This book deals with the international law concerning overseas territories and the right of. such territories to choose another relationship with their mother country. Many examples are studied, such as the British, French, American, Danish and New Zealand territories. May such islands choose to become independent, or to become an integral part of the mother country? Do they have the freedom to determine their own political status, to act on the international scene? The case of the Dutch territories in the Caribbean is dealt with in more detail, specifically their constitutional relationship to the Netherlands and the European Union. Through comparison of the different solutions that other states have chosen, a number of best practices are identified. \$130.00: Hb: 978-9-067-04279-6: 400 pp.

\section{WORLD TRADE ORGANIZATION} DISPUTE SETTLEMENT REPORTS 2006

The Dispute Settlement Reports of the World Trade Organization (WTO) include Panel and Appellate Body reports, as well as arbitration awards, in disputes concerning the rights and obligations of WTO Members under the provisions of the Marrakesh Agreement Establishing the World Trade Organization. These are the only authorized paginated reports in English. As such, they are an essential addition to the library of every practicing and academic trade lawyer, and will be widely consulted by students taking courses in international economic or trade law. The WTO authorized printed DSR volumes commenced publication with DSR, 1996\% I. Publication of the Cambridge printed edition follows the WTO website publication of all new reports, which will continue in the three working languages of English, French and Spanish. Once a report has been released on the WTO website it will be published in the next Cambridge printed volume.

\section{Volume 7 - Pages 2767-3184}

Reports on European Communities - Measures Affecting the Approval and Marketing of Biotech Products

\$190.00: Hb: 978-0-521-89660-3: 418 pp.

Volume 8 - Pages 3185-3788

Reports on European Communities - Measures Affecting the Approval and Marketing of Biotech Products

\$190.00: Hb: 978-0-521-89661-0: 603 pp.

Volume 9 - Pages 3789-4408

Reports on European Communities - Selected Customs Matters.

\$190.00: Hb: 978-0-521-89662-7: 619 pp.

Volume 10 - Pages 4409-4718

Reports on European Communities - Selected Customs Matters.

\$190.00: Hb: 978-0-521-89663-4: 309 pp.

Volume 11 - Pages 4719-5084

Reports on United States - Tax Treatment for "Foreign Sales Corporations", Second Recourse to Article 21.5 of the Understanding on Rules and Procedures Governing the Settlement of Disputes by the European Communities and United States - Investigation of the International Trade Commission in Softwood Lumber from Canada, Recourse to Article 21.5 of the Understanding on Rules and Procedures Governing the Settlement of Disputes by Canada.

\$190.00: Hb: 978-0-521-89664-1: 365 pp.

\section{Volume 12 - Pages 5085-5494}

Reports on United States - Final Dumping Determination on Softwood Lumber from Canada, European Communities - Customs Classification of Frozen Boneless Chicken Cuts, Chile - Price Band System and Safeguard Measures Relating to Certain Agricultural Products and United States - Measures Affecting the CrossBorder Supply of Gambling and Betting Services.

\$190.00: Hb: 978-0-521-89665-8: 410 pp.

\section{Complete Set:}

Volumes 1996-Present

\$13,450.00: 96 Hbs: 978-0-521-82322-7

For more information on current and previous volumes in the set, please visit our website at www.cambridge.org/us/law

\section{International Law Reports}

Elihu Lauterpacht, and Christopher

J. Greenwood, in association with

Andrew Oppenheimer, and assisted

by Karen Lee

The International Law Reports is the only publication in the world wholly devoted to the regular and systematic reporting in English of decisions of international courts and arbitrators as well as judgments of national courts. Since the Reports began in 1922 over 10,000 cases have been reported in full or digest form. This new companion volume is an indispensable guide to the Reports themselves, and also an essential compendium to the vast range of international law jurisprudence over the last eighty years. The Tables of Cases provide a complete consolidated list of cases included in volumes 1-125, arranged alphabetically and by jurisdiction and date. Early volumes in the series have been revisited in order to bring previous reference practice into conformity with current practice. This new consolidation offers easy access through a single point to the whole of international law jurisprudence in the years 1918-2000.

\section{Volume 133}

Reports on, among others, the 2007 decision of the European Court of Human Rights in Behrami and Saramati, the judgment of the Court of Appeal of Singapore in CAA v. Singapore Airlines and the related Canadian decision, and the English decisions of the High Court, Court of Appeal and House of Lords in Al-Skeini.

\$245.00: Hb: 978-0-521-87922-4: $820 \mathrm{pp}$

Complete set: Volume 1-129

\$17,678.00: Hbs: 978-0-521-46926-5

$92,018 \mathrm{pp}$.

For more information on current and previous print volumes, please visit our website at www.cambridge.org/us/law

Cambridge University Press and

Justis Publishing

are proud to announce

The International Law Reports Online

From the end of 2008 for the first time ever the full archive of the International Law Reports will be available online via the fully-searchable, award-winning Justis platform. Check us out at www.justis.com/ilr

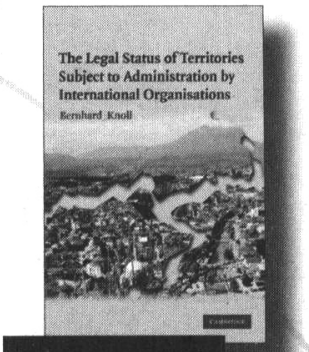

포․
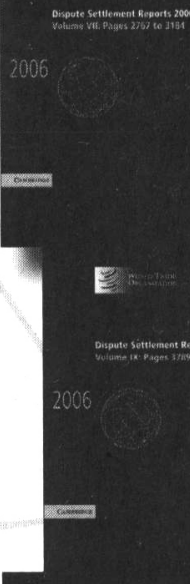

?
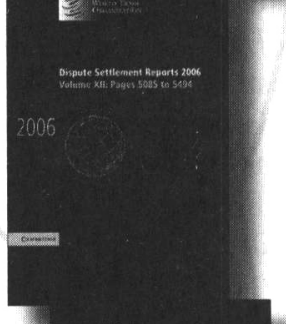

E
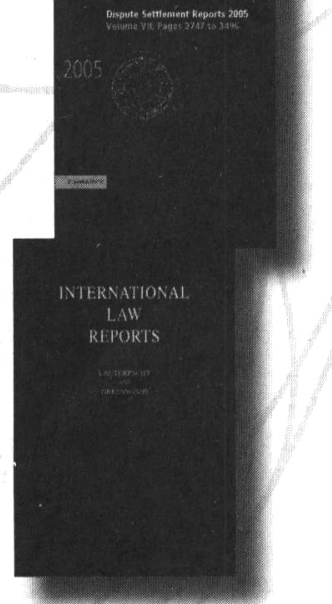

\section{.}




\section{Essays on Human Rights}

by Boštjan Zupančič

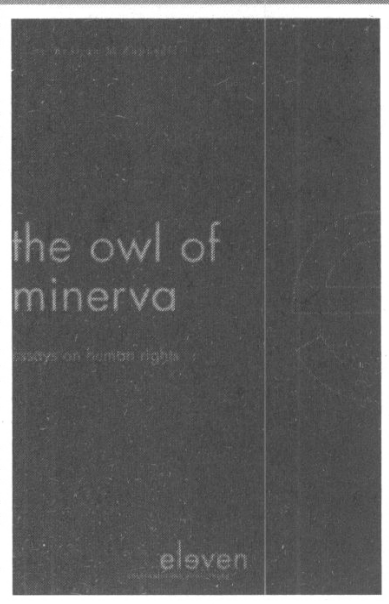

isbn $978-90-77596-47-0$ Softbound, xiv $+448 \mathrm{pp}$. Publication date: Dec 2007 Price: $€ 75$ / US\$ 109

\section{About the Author}

The title of the book is taken from Hegel and refers to the idea that philosophy cannot be prescriptive because it understands only in hindsight. The same holds true for conceptions of human rights. Based on his many years of experience in the field, the author shares his thoughts about human rights and the role it plays in society.

In these thought-provoking essays, the author examines the dialectic relationship between 'rule of law' and 'law and order'; between 'state' and 'individual'; 'judicial power of logic' vs. 'executive logic of power'. These dynamic contradictions are never resolved. On the contrary, they are the motor of development and inspire judicial reasoning and the balancing of justice vis-à-vis power and arbitrariness.

Boštjan M. Zupančič, dipl. iur. (Lab.), LL.M. and S.J.D. (Harvard), Professor of Law (US and Slovenia), former Justice of the Constitutional Court of Slovenia, former Vice-Chairman of the UN Committee against Torture, President of the Third Section of the European Court of Human Rights.

\section{Table of Contents}

Foreword; Section I: Human Rights in the Context of Constitutional Criminal Procedure; Chapter One: Introduction; Chapter Two: Adjudication and the rule of law; Chapter Three: Truthfinding and impartiality in the criminal process; Chapter Four: The crown and the criminal: The privilege against self-incrimination; Chapter Five: Plea- bargaining; Chapter Six: Conclusion. Section II: Human Rights in the Context of Substantive Criminal Law; Chapter Seven: Introduction; Chapter Eight: Beccaria: Theories on punishment and legal formalism; Chapter Nine: Punishment and its influence on normative integration; Chapter Ten: On legal formalism: The principle of legality in criminal law; Chapter Eleven: Conclusion. Section III: Essays on Human Rights in the Context of Constitutional and International Law; Chapter Twelve: On the interpretation of legal precedents and of the judgements of the European Court of Human Rights; Chapter Thirteen: Access to Court: As a Human Right according to the European Convention of Human Rights; Chapter Fourteen: Morality of Virtue vs. Morality of Mere Duty or Why do penalties require legal process whereas rewards do not? Authors Index; Subject Index; Bibliography.

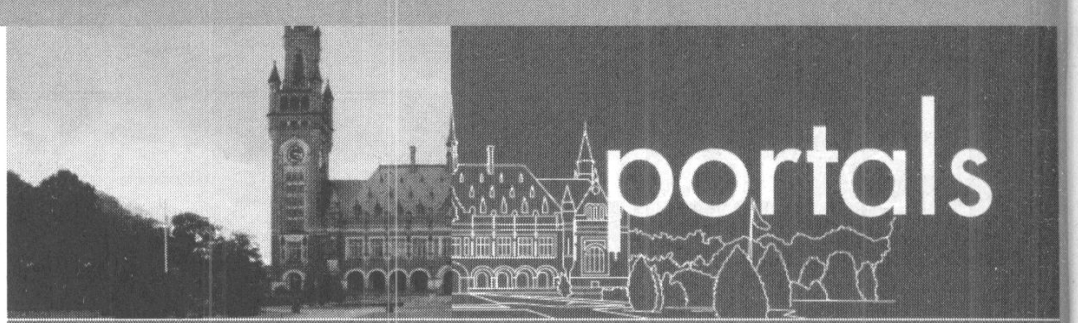

\section{International Cases in Context}

edited by René Lefeber; Legal Adviser Ministry of Foreign Affairs, The Netherlands

The International Cases in Context Portal (ICIC) classifies and structures all important international cases, thus making the body of international case law more accessible. Starting with the leading cases of the International Court of Justice, this service gives an analysis of each case and sets out its relevance for the development of international law. Other cases will be added at a regular basis and in future, cases of other international tribunals will also be included.

ICIC online gives the full text of each case, including various search possibilities and hyperlinks to relevant primary source documents, such as treaties and resolutions. All essential facts such as opinions, case name, parties, date, source, are incorporated as well.

ICIC can be searched and browsed in different ways:

- search all cases;

- search by authority, subject area, date, parties, individual opinions, or legal instrument;

- search in case analysis, or by keywords in case analysis;

- search full text.

The result list will give you a listing of cases. For each case you will find:

- case information (case type; authentic language; authority; official publication; date; subject areas; parties)

- case analysis (case history and legal findings)

- case texts (full text of submission, judgments, orders, individual opinions)

- bibliography (compiled by the Peace Palace Library)

- relevant cases (hyperlinked)

- relevant legal instruments (hyperlinked to full text)

ICIC covers the ICJ and PCIJ cases. Case analyses will be added on an ongoing basis.

If you would like to have trial access or take out a subscription, please contact sales@elevenpub.com

2008 subscription price: $€ 300$ per year

Eleven International Publishing is a new international legal publishing company, based in the Netherlands. ELEVEN's aim is to support the use of international law by offering high quality and timely publications. ELEVEN is active in various areas of law. Please visit our website www.elevenpub.com for more information on our publishing programme.

P.O. Box 358

3500 AJ Utrecht

The Netherlands

$\mathrm{T}:+31(0) 302310545$

F: + $31(0) 302258045$
Distribution in North America: ISBS, 920 NE 58th Avenue, Suite 300, Portland, OR 97213-3786, USA Tel. toll-free: (1) 8009446190 ; F: +1 5032808832

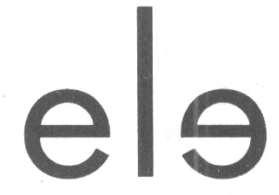

international publishing 

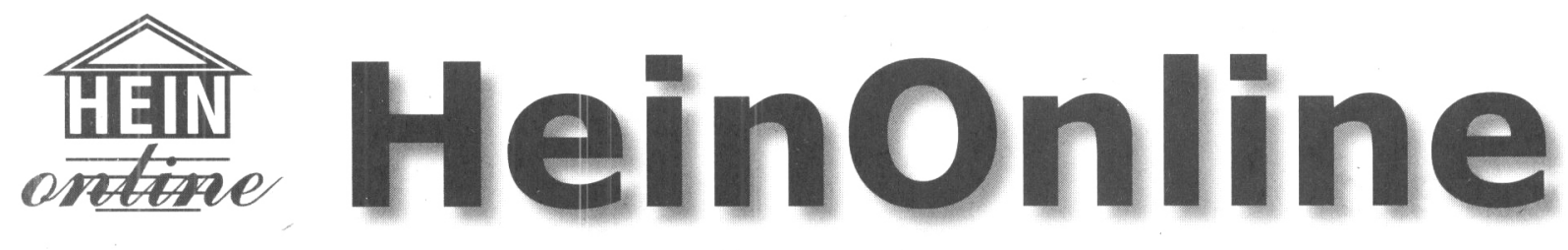

\section{Changing International Legal Research Forever}

\section{Kluwer Law Journal Library}

WeinOnline is pleased to welcome twelve Kluwer Law International journals to the HeinOnline database. Receive digital access to the back volumes of these leading European journals for a fraction of the print price!

Included are:

- Business Law Review

- Common Market Law Review

- European Business Law Review

- European Foreign Affairs Review

- European Public Law

- European Review of Private Law

- International Journal of Comparative Labour Law

\& Industrial Relations

- Journal of International Arbitration

- Journal of World Trade

- Legal Issues of Economic Integration

- World Competition

- $\quad$ European Energy \& Environmental Law Review

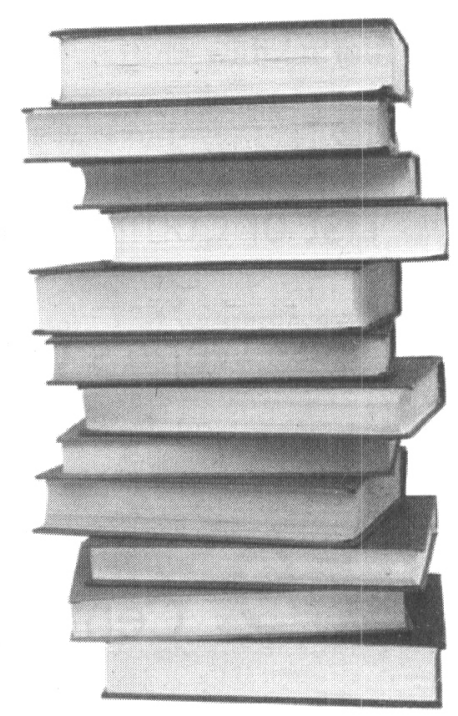

HeinOnline's Kluwer Law Journal Library is the BEST value!

150 Thousand pages

285 Volumes

4500 Articles

50 Cents an article

1 Low Price! 


\section{Is something missing from your research?}

\section{We can help.}

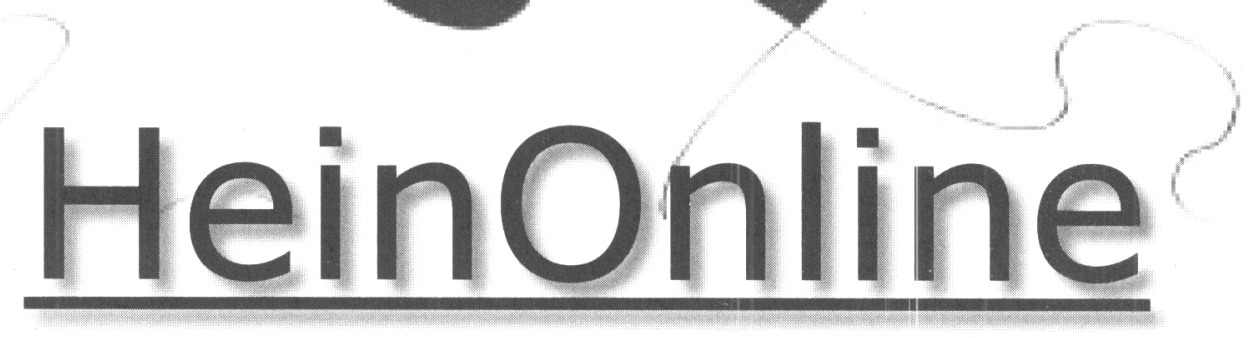

- Named to 2007 EContent 100 -

"List of Companies That Matter Most in the Digital Content Industry"

- World's Largest Image-Based Legal Research Database -

9 Centuries of legal history.

37 Million pages of relevant legal information.

14 valuable collections included in the Core subscription.

+9 Additional a-la-carte collections available.

\section{Priceless resource at your fingertips!}




\section{Foreword}

The dramatic growth in the international legal field makes it nearly impossible for scholars and practitioners-let alone the general public - to keep abreast of the most important international legal developments. Just this one issue of International Legal Materials reflects the diversity of issues, institutions, and actors in the international legal field today. Our field covers everything from the relationship of international and domestic law to human rights issues concerning freedom of expression. International law also emanates from hundreds of institutions and tribunals at the international, regional, and national level.

Fortunately international lawyers struggling to keep on top of it all can rely on our staff and Editorial Advisory Committee to sift through the vast array of documents, identify those that are truly significant, and highlight them in International Legal Materials and our bi-monthly electronic bulletin, International Law in Brief. The Society's periodic ASIL Insights provide additional analysis of particularly high-profile developments.

Our readers have long come to expect that International Legal Materials will help them keep track of what is new and important in international law. Now, they can look to this bulletin to also explain why. Beginning last year, ASIL has complemented every document published in International Legal Materials with an introductory note from one of the many experts ASIL counts among its members. These notes provide summaries of the documents and key insights into their significance. In this volume we feature notes by Mark Wojcik, Scott Lyons, John Cerone, Sungjoon Cho, and Alejandro Escobar. We are extremely grateful to these authors, and we are confident that you will value their contributions as well.

In 2008, we will be exploring additional innovations to keep this publication as timely and valuable as it has been for decades. Please send us your comments and suggestions as we continue our efforts to meet the evolving needs of the international legal community.

Sincerely,

Elizabeth Andersen

Chair

Editorial Advisory Committee

International Legal Materials 


\section{INTERNATIONAL LEGAL MATERIALS ${ }^{\circledR}$}

\section{Statement of Editorial Policy}

International Legal Materials is a core publication of The American Society of International Law that reproduces texts of documents reflecting the broad scope and evolution of international law. The range of covered subjects has expanded from traditional topics such as international organizations, jurisdiction, and international trade to include developments in fields such as intellectual property, environmental law, nuclear non-proliferation, human rights, and international criminal law.

International Legal Materials serves as both a bi-monthly information service and a widely recognized archive of international law documents for a diverse, global community of legal scholars, government officials, private practitioners and institutions sharing a common interest in international law. To meet the varied demands of such a readership, documents are selected from world-wide sources on the basis of their present and future legal significance.

International Legal Materials is prepared for publication in Washington, D.C. with both the advice of the Editorial Advisory Committee and the assistance of Corresponding Editors around the world. In order to reproduce the texts of selected documents under tight production schedules, the best available source is used, whether electronic or printed.

Readers are invited to send comments to:

Susan A. Notar, Esq.

Managing Editor, International Legal Materials

The American Society of International Law

2223 Massachusetts Avenue, NW

Washington, DC 20008-2864 


\section{Subscription Information}

International Legal Materials (ISSN 0020-7829) is published bi-monthly (in January, March, May, July, September and November) by The American Society of International Law, 2223 Massachusetts Avenue, NW, Washington, DC 20008-2864.

For 2007 subscriptions, the rate for Society members in the U.S. is $\$ 150$; outside the U.S., $\$ 215$ (airmail delivery). The rate for non-members of the Society is $\$ 255$; outside the U.S., $\$ 315$ (airmail delivery). Subscriptions are on an anniversary basis of twelve months starting from start of subscription.

\section{Back Issues and Indices}

ILM Volumes 1-42 (1962-2003) are available from William S. Hein \& Co., 1285 Main Street, Buffalo, NY 142091987, toll-free (800) 828-7571, http://www.wshein.com. Hein's prices for back issues vary according to the ILM volume.

Both an annual table of contents and an annual index are carried in the November issue of each volume. Decennial Indices for International Legal Materials are available from Hein for the following periods: 1962-1969, 19701979, and 1980-1989.

ILM is also indexed by ABC POL SCI, IBZ-International Bibliography of Periodical Literature, Marine Affairs Bibliography, and Public Affairs Information Service.

\section{Online Access and Microfiche}

International Legal Materials is available online through:

LEXIS/NEXIS - http://www.lexis-nexis.com

Westlaw - http://www.westlaw.com

Complete and odd volumes of International Legal Materials are available on microfiche from William S. Hein \& Company, 1285 Main Street, Buffalo, NY 14209-1987, toll-free (800) 828-7571, http://www.wshein.com

\section{ILM Tables of Contents - Online}

Recent ILM Tables of Contents are stored at The American Society of International Law website, http/l:www.asil.org. The Society's search engine can also be used to find the ILM citation of recently reproduced documents.

(C) The American Society of International Law 2006

\section{Change of Address, Claims and Correspondence}

Please inform the ASIL Service Center of a change of address in writing at least 60 days prior to moving in order to assure uninterrupted receipt of ILM. Your post office will not automatically forward your subscription. Claims for undelivered issues must be made in writing within three months of the publication date, which is available online at $\langle$ http://www.asil.org/claims.htm>.

All correspondence regarding subscriptions and claims should be addressed to:

\author{
ASIL Service Center \\ Association Headquarters \\ Telephone: (856) 380-6810 \\ FAX (202) 986-4234 \\ http://www.asil.org, or e-mail: services@asil.org
}

\section{Advertising}

Inquiries about advertising rates and specifications should be directed to the Marketing Manager at the above address, phone or fax (but not e-mail address).

\section{Authorization to Photocopy}

Authorization to photocopy items for internal or personal use (beyond that permitted by Sections 107 and 108 of the U.S. Copyright Law), or for the internal or personal use of specific clients, is granted by The American Society of International Law for users registered with the Copyright Clearance Center (CCC) Transactional Reporting Service, provided that the base fee of $\$ 10$ per copy, plus $25 \notin$ per page, is paid directly to CCC, 222 Rosewood Drive, Danvers, MA 01923-4510, http://www.copyright.com

For those organizations that have been granted a photocopy license by CCC, a separate system of payment has been arranged. The fee code for users of the Transactional Reporting Service is: $0020-7829 / 98 \$ 10.00+.25$.

For academic course reprints, please contact the ILM Office at 2223 Mass. Ave., NW, Washington, DC 20008-2864.

Periodicals postage paid at Washington, $\mathrm{DC}$ and additional mailing offices. POSTMASTER: Send address changes and returns to ILM, 2223 Massachusetts Avenue, NW, Washington, DC 20008-2864. Return postage guaranteed. 
The ILM Office welcomes any effort to bring suitable documents to the Office's attention. Electronic files or web links are required for publication, although printed texts can be used for initial deliberations regarding republication.

The authenticity (i.e. official version status) of submitted documents must be easily verifiable. This is facilitated by submitting files or print versions which are clearly attributable to the original source, or by providing links to documents on the original source's official website.

If the official version of a document is not available in English, an unofficial translation is acceptable. The original text must accompany such a translation.

\section{Introductory Notes}

Introductory Notes are brief articles from one to three pages in length which are intended to provide background information for a document reproduced in ILM.

For example, an Introductory Note for a treaty might include a short history of the negotiations, the dates of signature and entry into force. An Introductory Note for legislation would give its history and international significance, while one for judicial proceedings would provide the background of the case.

The views of authors in Introductory Notes are their own and do not necessarily reflect those of either the American Society of International Law or the Managing Editor.

\section{Acceptance of Materials and Corrections}

Print submissions cannot be returned: Translators and others submitting material will be notified of the acceptance of their document for publication.

Once a translation or Introductory Note has been accepted for reproduction, The American Society of International Law will send a publication agreement to the author.

Translators and Introductory Note Authors shall be acknowledged in International Legal Materials.

In some cases minor editorial or typographical alterations may be made without contacting the author or translator. Major corrections will be sent to the author or translator for approval. Corrected Introductory Notes or translations must be returned within the time specified.

\section{Contributions and Correspondence}

Please address all correspondence to:

Susan A. Notar, Esq.

Managing Editor, International Legal Materials

2223 Massachusetts Avenue, NW

Washington, DC 20008-2864

Telephone: (202) 939-6000

FAX: (202) 797-7133

e-mail: snotar@asil.org

\section{International Law In Brief}

The Attorney-Editors of International Legal Materials also publish the e-mail newsletter International Law In Brief, which contains objective abstracts of recently released documents pertinent to international law.

Documents abstracted in International Law In Brief are later considered for reproduction in International Legal Materials.

A complete International Law In Brief archive is located at The American Society of International Law website (http://www.asil.org). A search engine provides an easy way to find abstracts of specific documents.

The International Law In Brief publication is free, but has an independent subscription.

To subscribe, send an e-mail to:

ILIB-request@listserve.asil.org

Leave the subject blank, and in the message space write: Subscribe

Or, go to the registration website at:

http://web3.ags.com:81/guest/RemoteListSum mary/ILIB

For further information, please contact:

Susan A. Notar at snotar@asil.org 
Managing Editor

Susan A. Notar, Esq.

\title{
Editorial Advisory Committee
}

\author{
Elizabeth Andersen, Chair \\ Evan T. Bloom \\ Christina M. Cerna \\ John R. Crook \\ Jane Dalton \\ Anne Joyce
}

\author{
Nancy L. Perkins \\ David Stewart \\ Charles Owen Verrill \\ Jeffrey Walker \\ Bruce Zagaris \\ Nassib G. Ziadé \\ Members Emeriti \\ John Lawrence Hargrove
}

\section{ILM Corresponding Editors}

Judge Leslie Alden (Int'1 Ass'n Women Judges)

Evelina Teubal Alhadeff (Mercosur, Argentina)

Don Anton (Int'l Env., LOS)

David J. Attard (Malta)

Paolo Bargiacchi (Int'l Hegemonic Law)

Welber Barral (Brazil, Int'l Trade)

Delroy Beckford (Trade Remedies)

Jean-François Bellis (European Communities)

Charles H. Brower, II (Pub. Int'l, Arbitration)

Gian Luca Burci (Int'1 Health)

William E. Butler (CIS)

David JA Cairns (Investment Arbitration)

James H. Carter (U.S. Second Circuit)

Elizabeth Chien Hale (IP)

Sudhir Chopra (India)

Carl Q. Christol (Communications, Outer Space)

Nivoi Christopoulou (European Union)

John P. Cogan, Jr. (U.S. Fifth Circuit)

Alice De Jonge (Multinational Corp. Resp.)

Melaku Geboye Desta (AU, Agriculture, WTO)

Christian De Vos (Human Rights)

Janelle Diller (Int'l Labor Law)

John R. Dugard (Southern Africa)

Mete Erdem (Int'l Env., Turkey)

Stephanie Farrior (Int'l Hum. Rights)

Gustavo Ferreira Ribeiro (Brazil, Int'1 Economic Law)

Richard I. Fine (U.S. Ninth Circuit)

Kimberly Gahan (Nat'l Security)

Hannah R. Garry (Int'1 Human Rights)

Giacomo Gattinara (E.U)

Dencho G. Georgiev (Bulgaria)

Chiara Giorgetti (Int'l Env.)

Maria Gavouneli (Greece, Cyprus, LOS)

Kevin R. Gray (Int'1 Trade and Environment)

Dermot Groome (Int'l Humanitarian)

Moritaka Hayashi (LOS, Int'l Fisheries Law)

Eckhard Hellbeck (Int'l Dis. Res.)

Jean-Marie Henckaerts (Int'1 Humanitarian Law)

Cecil Hunt (Anti-Bribery Laws and Regulations)

Larry D. Johnson (Int'l Atomic Energy Agency)

Sami Kallel (Maghreb)

Mark Kantor (Int'l Bus., Int'1 Arbitration)

Susan L. Karamanian (Investment, Arbitration)

Nicholas Karambelas (Commercial Treaties, LOS)

Kenneth Klein (Int'l Taxation)

Christina Knahr (Int'l Investment Arbitration)

Artur Kowalski (Poland, Pub. Int'l)

Jeffrey D. Kovar (Pub. and Private Int'l Law)

Karin Landgren (Children)

Arnold H. Leibowitz (Immigration)
Frankie F.L. Leung (Hong Kong)

John Linarelli (Int'l Public Procurement)

Keith N. Loken (Int'l Econ. Law)

Jim Lynch (Int'1 Tax)

Pedro J. Martinez-Fraga (Int'1 Litigation)

Andrew Mitchell (WTO)

Saira Mohamed (Int'l Human Rights)

Jason Morgan-Foster (ICJ, ILC)

Daryl A. Mundis (ICC, ICTR, ICTY)

Boldizsár Nagy (Hungary)

Michael O'Boyle (European Court of Human Rights)

Jason Palmer (Pub. Int'l)

Eric Pelofsky (Int'1 Orgs.)

Fabrizio Pagani (OECD)

John R. Pate (Andean Community of Nations)

T. Michael Peay (Pub. Int'l)

Hernan Perez-Loose (Int'l Investment)

Ryan Phair (Pub. Int'l)

Shawn Pompian (Int'l Trade)

Charles H. Poncet (Switzerland)

Amelia B. Porges (WTO)

Norman Printer (Int'l Humanitarian)

Vikram Raghavan (World Bank)

Heiko Recktenwald (German, WIPO)

August Reinisch (European Law)

Kenneth M. Rosen (Reg. Int'l Bus.)

Timothy Rudy (OAS)

Ewa Sakiewicz-Munnerlyn (Poland)

Gerald S. Schatz (Bio-Medical Ethics/Health)

Richard F. Scott (International Energy Agency)

Jeremy Sharpe (Int'l Dis. Res.)

William Slomanson (Pub. Int'l)

Henri Smets (Int'1 Env. Law, OECD)

Stefaan Smis (Belgium)

Brigitte Stern (France)

Sompong Sucharitkul (Southeast Asia and the Pacific)

Jiri Toman (Law of War)

Antônio Augusto Cançado Trindade (Brazil, IACHR)

Alexander Umole (Nigeria, IBT)

Kim Van der Borght (Belgium)

Jorge A. Vargas (Mexico)

Manuel E. Ventura-Robles (IACHR)

Thomas W. Wälde (Energy Law, Int'l Investment)

Rebecca M.M. Wallace (United Kingdom)

John Wilson (Private Int'l Law)

Rick Wilson (Human Rights)

Anthony Winer (Caspian Sea, Corruption)

Yozo Yokota (Japan)

Simon Young (Money Laundering)

Alberto Zuppi (Int'1 Crim.) 


\section{InTERnational Legal Materials}

Volume 47 - No. 3 - 2008

- Contents -

\section{JUDICIAL AND SIMILAR PROCEEDINGS}

United States Supreme Court: Medellin v. Texas

Introductory Note by Mark E. Wojcik

Extraordinary Chambers in the Courts of Cambodia Pre-Trial Chamber Decision on Appeal

against Provisional Detention Order of Kaing Guek Eav

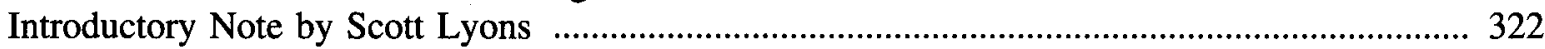

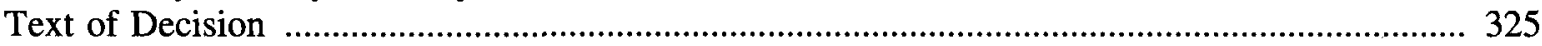

European Court of Human Rights: Lindon v. France

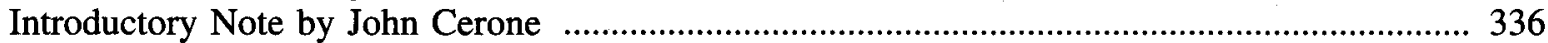

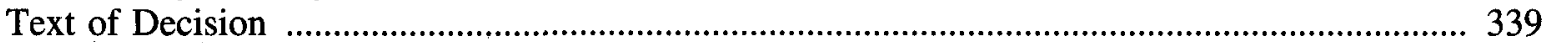

World Trade Organization: Measures Affecting the Supply of Gambling and Betting

Services (Award)

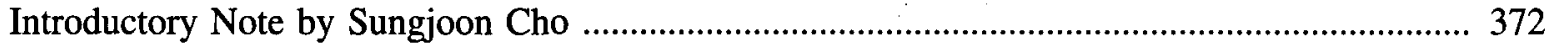

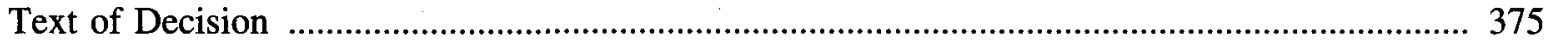

International Centre for the Settlement of Investment Disputes (ICSID): Azurix Corp. v.

The Argentine Republic Decision on the Argentine Republic's Request for a Continued

Stay of Enforcement of the Award

Introductory Note by Alejandro Escobar ................................................................................. 445

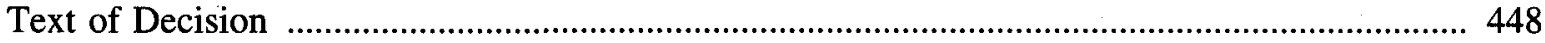

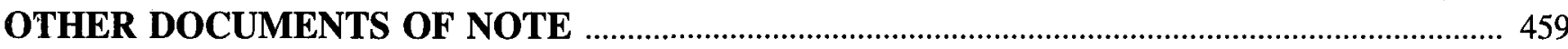

VOLUME 47 - NUMBER 3 